AC 2010-412: STATUS STUDY OF CAD/CAM/CNC INTEGRATION IN SOUTH TEXAS TECHNICAL COLLEGES

Farzin Heidari, Texas A\&M University, Kingsville 


\title{
Status Study of CAD/CAM/CNC Integration in South Texas Technical Colleges
}

\begin{abstract}
The CAD/CAM/CNC system is an advanced technology widely used to manufacture an array of products. The CAD system is both the hardware and software components that extract $2 \mathrm{D}$ or $3 \mathrm{D}$ CAD information. This information is then used to generate the desired Computer Numerical Control (CNC) program for milling, drilling, lathe, and other manufacturing processes. ${ }^{5}$ Recently, the CAD/CAM/CNC system has extended its applications in medical technology. The benefits have been exploited in dentistry to fabricate crown and bridge substructures. Furthermore, medical capabilities are used to generate 3D models of organs for medical observations. $^{3}$
\end{abstract}

Significant measures have been taken by South Texas technical colleges to implement $\mathrm{CAD} / \mathrm{CAM} / \mathrm{CNC}$ technology within their programs. However, a regional study has not been conducted to determine the nature and potential to implement CAD/CAM/CNC programs in South Texas.

\section{Introduction}

The CAD/CAM process consist various design-based components to include modeling and prototyping, CAM processing, and generating G-code programs. A G-code program enhances different CNC computer driven machine tools such as CNC mill and CNC lathe. ${ }^{2}$ Actual operations using CNC machine tools finalize the CAD/CAM/CNC process. Complimentary, these processes require a major knowledge-based component to complete this system. Therefore, efficiency of part production solely depends on the machinist's mastery of all processes. Using the CAD/CAM/CNC system as an effective tool cannot be achieved unless a machinist has acquired an in depth understanding through an advanced technical degree in $\mathrm{CAD} / \mathrm{CAM} / \mathrm{CNC}$ systems.

Leading technical colleges reference $\mathrm{CAD} / \mathrm{CAM} / \mathrm{CNC}$ programs as advanced manufacturing programs. An Associate of Applied Science (A.A.S) in advanced manufacturing program is earned upon successfully completing both required general education and core technology coursework. Student success depends on their ability to demonstrate mastery through all coursework required in degree plan. Table 1 delineates earned credit hours for each course in this degree plan (Northwestern Michigan College, 2009 degree plan). The degree plan consists of 64 total credit hours to include 18 credit hours of drafting and design, 6 credit hours of manual 
machining, 6 credit hours of CNC and CAM, and 12 hours of other related technical courses. The remaining 22 credit hours are allotted to general education coursework (Table 1).

\begin{tabular}{|c|c|c|}
\hline \multicolumn{3}{|c|}{$\begin{array}{l}\text { Associate in Applied Science Degree (A.A.S) } \\
\text { Advanced Manufacturing Program }\end{array}$} \\
\hline General Education Requirements & & 22 credit hrs \\
\hline \multicolumn{3}{|l|}{ Supporting Fields for Machining Technology } \\
\hline Print Reading Sketching & 3 hours & \\
\hline Basic Metallurgy & 3 hours & \\
\hline Math for Manufacturing & 3 hours & \\
\hline \multirow[t]{2}{*}{ Advanced Manufacturing Project } & 3 hours & \\
\hline & & 12 credit hrs \\
\hline \multicolumn{3}{|l|}{ Manual Machining requirements } \\
\hline Machining I & 3 hours & \\
\hline \multirow[t]{2}{*}{ Machining II } & 3 hours & \\
\hline & & 6 credit hrs \\
\hline \multicolumn{3}{|l|}{ 2D and 3D CAD requirements } \\
\hline Computer Aided Drafting & 3 hours & \\
\hline Mechanical Drafting & 3 hours & \\
\hline Detail Drafting & 3 hours & \\
\hline Geometric Dimensioning \& Tolerance & 3 hours & \\
\hline Part and Assembling Modeling & 3 hours & \\
\hline \multirow[t]{2}{*}{ Advanced Part \& Assembling Modeling } & 3 hours & \\
\hline & & 18 credit hrs \\
\hline \multicolumn{3}{|l|}{$\mathrm{CNC}$ and CAM requirements } \\
\hline CNC Programming & 3 hours & \\
\hline \multirow[t]{2}{*}{ Computer-Aided Machining } & 3 hours & \\
\hline & & 6 credit hrs \\
\hline Prograr & irements & 64 credit hrs \\
\hline
\end{tabular}

Table 1: CAD/CAM/CNC or Advanced Manufacturing Program Degree Plan

\section{CAD/CAM/CNC Training}

The CAD/CAM/CNC training component consist of the following core technology coursework: drafting and designing, 2D drawing and 3D solid modeling, manual machining, CNC 
programming, and CAM programming. ${ }^{1}$ Graduates of these programs seek job opportunities requiring a CAD drafter or 3D modeler, $\mathrm{CNC}$ or CAM programmer, $\mathrm{CNC}$ operator or a composite of these technologies.

Drafting and Design: Computer Aided Drafting (CAD) technology is a widely used drawing and modeling program for CAM processes. CAD in its simplest form presents a 2D shape.

Connecting an array of entities such as lines, arcs, points and curves creates a 2D drawing. A 2D vector-based drafting system is applicable for drawing physical components. Naturally, an operator programming vector-based or solid modeling systems require various modalities of thinking to create the desired geometric shape. Operators master this technique through handson learning, analyzing design, and identifying necessary steps to complete drawing.

CAM Application: The CAM application consist a 3D modeling component. A 3D model is created by extruding a 2D flat geometric object to a 3D block. Operator has the capability to add, subtract, stretch or adjust the 3D block to meet desired model. Models can be viewed from a variety of angles. The generated 3D model can be saved as a file and imported into other applications such as prototyping or other CAM processes. Students taking design and 3D modeling will also be introduced to program features allowing them to create, edit, analyze and plot $3 \mathrm{D}$ models.

Manual Machining: Manual machining is referenced as learning the operation of conventional machine tools. This technology has not been changed since the 1950's. Students learn basic skills and machining techniques required to operate the following machines; horizontal and vertical mills, engine lathe, drill press, surface and pedestal grinders. Students' skills are enhanced through hands-on machine tool practices including precision measurements, blueprint reading and the heat treatment of metals.

CAM Programming: Computer Aided Manufacturing (CAM) is computer-based software used by machinist to manufacture various products. Students are exposed to concepts of CAM software to generate programs for CNC machine tools. The generated tool path is verified using a graphic simulation prior to running program.

CNC Programming: CNC programming introduces students to $\mathrm{CNC}$ machine programming concepts, set-up, and operation. Instruction will also include coordinate systems, process planning, cutter compensation, and canned cycles. Students will write and edit programs for the CNC machines using $\mathrm{G}$ and $\mathrm{M}$ codes.

\section{South Texas Technical Colleges}


There are six technical colleges in South Texas offering an Associate of Applied Science (A.A.S) degree in machining technology and/or computer drafting and design technology. Each technology degree is independent of each other and classified under different technology departments. In some cases they are housed in different buildings. Technical colleges included in this study are: Texas State Technical College in Harlingen, South Texas College in Mc Allen, Texas South-most College in Brownsville, Laredo Community College in Laredo, Costal Bend College in Alice and Beeville and Del Mar College in Corpus Christi. These colleges prepare students for industrious employment with drafting and machining carriers in South Texas. The demographic information and programs offered are shown in Table 2. Machining technology, computer drafting, and design degrees are offered at all six colleges. Degree plans were evaluated to identify the present status of CAD/CAM/CNC training in the South Texas technical colleges.

Texas State Technical College (Harlingen): The purpose of the machining technology department at TSTC is to provide and maintain a high quality certificate and A.A.S level technical education program for South Texas residents. Additionally it provides manufacturing industries in Texas with highly qualified trained employees. The TSTC degree plan requires 72 total credit hours for graduation amongst the following areas: 21 credit hours in general education, 21 credit hours or seven classes supporting fields for machining technology, 24 hours of basic to advance manual machining of various machine tool operations, and 6 hours of CNC programming to include MCHN2303 Fundamentals of Computer Numerical Control and MCHN2335 Advanced CNC Machining. This degree plan lacks the advanced technology coursework in Computer Aided Manufacturing (CAM), 2D Computer Aided Drafting (CAD) or 3D solid modeling.

\begin{tabular}{|c|c|c|c|c|}
\hline Technical College & City & Degrees Offered & Degree Plan & $\begin{array}{c}\text { Total College } \\
\text { Enrollment }\end{array}$ \\
\hline Texas State Technical College & Harlingen & $\begin{array}{l}\text { Machining Technology } \\
\text { Computer Drafting \& } \\
\text { Design Technology }\end{array}$ & $\begin{array}{l}72 \text { Credit Hours } \\
72 \text { Credit Hours }\end{array}$ & 9, 190 Students \\
\hline South Texas College & McAllen & $\begin{array}{l}\text { Precision Manufacturing } \\
\text { Technology } \\
\text { Computer Aided Drafting \& } \\
\text { Design }\end{array}$ & $\begin{array}{l}69 \text { Credit Hours } \\
70 \text { Credit Hours }\end{array}$ & 18, 466 Students \\
\hline Del Mar College & Corpus Christi & $\begin{array}{l}\text { Industrial Machining } \\
\text { Applied Technology } \\
\text { Architectural/Drafting } \\
\text { Technology }\end{array}$ & $\begin{array}{l}69 \text { Credit Hours } \\
67 \text { Credit Hours }\end{array}$ & 25, 761 Students \\
\hline Texas South-most College & Brownsville & $\begin{array}{l}\text { Machining Technology } \\
\text { Computer Aided Drafting } \\
\text { Technology }\end{array}$ & 66 Credit Hours & 28,322 Students \\
\hline Costal Bend College & Alice/Beeville & $\begin{array}{l}\text { Machinist Program (Alice) } \\
\text { Drafting \& Design } \\
\text { Technology (Beeville) }\end{array}$ & 62 Credit Hours & 8,016 Students \\
\hline Laredo Community College & Laredo & $\begin{array}{l}\text { No Machining Program } \\
\text { Computer Drafting \& } \\
\text { Design Technology }\end{array}$ & 72 Credit Hours & 18, 492 Students \\
\hline
\end{tabular}

Table 2: South Texas Colleges 
South Texas College (Mc Allen): The precision manufacturing technology program provides an environment to develop technical skills that are highly marketable to the South Texas industries. The STC degree plan requires 69 credit hours for graduation amongst following areas; 16 credit hours of general education, 30 credit hours or nine classes related to supporting fields of machining technology, 11 credit hours or three courses related to manual machining operations, 9 credit hours of CNC programming, and CAD/CAM and drafting to include INMT 1445 Computer Numerical Controls, INMT 1443 Computer Aided Design/Computer Aided Manufacturing, and DFTG 1313 Drafting for Special Occupations. The degree plan at STC also includes 3 credit hours in a program elective with the option of taking DFTG 2402 Machine Drafting or INMT 2334 Computer Numerical Control Programming.

Del Mar College (Corpus Christi): The industrial machining curriculum is designed to offer a practical approach in the study of machine tools and provides training in Computer Numerical Control (CNC) operations. Del Mar College's industrial machining applied technology degree plan requires 69 credit hours for graduation amongst the following categories; 18 credit hours of general education, 6 credit hours or two classes related to supporting fields of machining technology, 42 credit hours or 14 classes related to different skill levels in manual machining, and 3 credit hours of CNC programming offered under MCHN 2344 computerized Numerical Programming. Computer Aided Manufacturing (CAM), Computer Aided Drafting (CAD), or solid modeling courses are currently not offered nor included in the Del Mar College degree plan.

Texas South-most College: The machine technology program prepares students for entry level jobs in machining operations. Students acquire skills in CNC set-up and operation. The TSC degree plan requires 66 credit hours for graduation amongst the following categories; 15 credit hours of general education, 18 credit hours or six classes related to the supporting fields of machining technology, 24 credit hours of basic to advance manual machining of various machine tool operations, and 9 hours of $\mathrm{CNC}$ and CAD/CAM training to include MCHN 2303 Fundamentals of Computer Numerical Controlled, INMT 1343 Computer Aided Design Manufacturing, and MCHN 2331 Operation of CNC Turning Centers.

Costal Bend College (Alice): The machinist program provides students with opportunity to obtain up-todate training in various entry level machinist positions. The Costal Bend College offers students opportunity to earn an Association of Applied Science degree in machinist program. The degree plan requires 60 total credit hours for graduation amongst the following areas: 18 credit hours of general education, 10 credit hours or four classes related to supporting fields of machining technology, 23 credit hours of manual machining with various skill levels, and 9 hours of $\mathrm{CNC}$ programming to include MCHN 2303 Fundamentals of CNC Controls, MCHN 2335 Advance CNC Machining, and MCHN 2344 Computerized Numerical Control Programming. This degree plan currently lacks technology coursework in Computer Aided Manufacturing (CAM) or Computer Aided Drafting (CAD).

Laredo Community College (Laredo): Laredo Community College only offers Associated of Applied Science in computer drafting \& design technology. A machining technology program is presently not offered at this time. 


\section{Findings of the Study}

Evidence suggests the directional goals of six South Texas technical colleges are to establish technology programs offering advanced training in conventional shop machinist and maintenance machinist for local industries. South Texas College (STC) in Mc Allen is the only technical college in South Texas offering Computer Aided Design / Computer Aided Manufacturing, Drafting for Special Occupations, and Machine Drafting. The STC degree plan analysis clearly demonstrates an evolutionary attempt to meet industry demands toward advance manufacturing training.

Technology coursework amongst all six South Texas Technical College degree plans reflect a strong emphasis in manual machine tool training. Texas State Technical College, South Texas College, Del Mar College, South Texas-most College, and Coastal Bend College offer 24 credit hours, 11 credit hours, 42 credit hours, 24 credit hours, and 23 credit hours respectively in manual machine tool training. The number of credit hours related to manual machine tool training are significantly different nationwide with a typical advanced manufacturing program at 6 credit hours. Table 3 compares percentage of manual machining coursework and supporting fields to the total degree requirements of all coursework. The data presents a significant difference between South Texas Colleges to Northwest Michigan College, a leading school in advanced manufacturing.

The lack of computer aided design, 3D modeling and assembly drawing is evident in all the South Texas machine technology programs. In an advanced manufacturing program, a minimum of 18 hours of drafting and design courses are included in the degree plan. South Texas College in MC Allen is the only technical school in South Texas that requires DFTG 1313 Drafting for Special Occupations and DFTG 2402 Machine Drafting.

\begin{tabular}{|llc|}
\hline \multicolumn{1}{|c}{ Technical College } & City & $\begin{array}{c}\text { Percent of Courses Related to Manual } \\
\text { Machine Training \& Supporting Fields } \\
\text { Compare to the Total Program Requirements }\end{array}$ \\
\hline $\begin{array}{l}\text { Texas State Technical } \\
\text { College }\end{array}$ & Harlingen & $62 \%$ \\
\hline South Texas College & McAllen & $60 \%$ \\
\hline Del Mar College & Corpus Christi & $70 \%$ \\
\hline Texas South-most College & Brownsville & $64 \%$ \\
\hline Costal Bend College & Alice/Beeville & $55 \%$ \\
\hline
\end{tabular}




\begin{tabular}{|lc|}
\hline $\begin{array}{l}\text { Northwestern Michigan } \\
\text { College }\end{array}$ & Traverse City \\
\hline
\end{tabular}

Table 3: Percentage of Manual Machining Courses

\section{Conclusions}

The availability of fewer job opportunities for conventional machinist and maintenance machinist should experience a shift toward an advanced manufacturing curriculum offered by South Texas technical colleges. CAD/CAM/CNC and drafting instruction should be evident in all South Texas technical colleges. Technology skills gained by students in CAD/CAM/CNC and drafting coursework should be evident in students' ability to understand and demonstrate mastery with these technologies.

Rewarding careers are available for trained students in advanced manufacturing programs. Students may seek jobs opportunities as a CAD drafter or 3D model designer, CNC or CAM programmer, CNC operator or a composite of these technologies.

Implementing required technology coursework in advanced manufacturing programs in South Texas technical colleges will significantly improve educational standards and career opportunity for students in South Texas. The long term impact of integrating advanced manufacturing programs with $\mathrm{CAD} / \mathrm{CAM} / \mathrm{CNC}$ training will increase both science and technology literacy, while increasing standards of living and improving the quality of South Texas technical education.

\section{References}

1. Jeppson, J. (2000). Aerospace Manufacturing: Making HSM Work. Manufacturing Engineering, Available online: http://www.sme.org/cgi-bin/Find-articles.

2. Lin, Jonathon, 2006. Mastercam X Mill and Solids. Ann Arbor, MI: Scholar International Publishing Corporation

3. Kern, M (2009). CAD/CAM Was Just the Beginning. Dental Tribute, Available online: http//www.dentaltribute.com/articles/content/scope/specialties

4. Feuerstein, P. (2007). Inside Dentistry, New Changes in CAD/CAM: Part2 Lab Systems. pp. 82-86.

5. Shah, S. (1990).CADENCE, CAD/CAM: Who is Carrying the Ball? pp. 109-110. 